\title{
Nuevo ensayo para la determinación de frecuencias fundamentales longitudinales, transversales y torsionales en probetas de hormigón
}

\author{
New test for determining fundamental \\ transverse, longitudinal and torsional \\ frequencies of concrete specimens
}

J. M. GAIDIS y A. H. ROSEMBERG

\section{RESUMEN}

El método usado por la ASTM desde hace 25 años para la determinación de la durabilidad del hormigón después de sufrir ciclos hielo/deshielo ha sido el C215-60.

En este ensayo se comparan las frecuencias fundamentales de una probeta de hormigón. Este ensayo es ruidoso, lleva bastante tiempo y es bastante impreciso. En este trabajo se pone un nuevo método para medias frecuencias fundamentales. en el hormigón por simple golpe mediante la

TRANSFORMADA RAPIDA de FOURIER. EI nuevo

método es más rápido, más simple y más preciso.

\section{SUMMARY}

For twenty-five years the ASTM method used to determine reductions in concrete durability after freeze-thaw cycling has been C215-60. In this test the fundamental frequencies of a concrete specimen are compared. This test is time consuming, noisy and often inaccurate. In this paper a new method is proposed for measuring the fundamental frequencies of concrete to a single tap via a Fast Fourier Transform. The new test is faster, simpler and more accurate.
Durante muchos años ha sido práctica habitual en los laboratorios, para determinar la durabilidad del hormigón, la medición de las variaciones de las frecuencias fundamentales de resonancia de probetas sometidas a ciclos hielo/deshielo. Este método ha permanecido inalterado durante 25 años (ASTM C215-60). En este ensayo las probetas de hormigón se excitan a vibración mediante ondas sonoras de la banda audible y las vibraciones de resonancia resultantes se utilizan para determinar las frecuencias fundamentales (longitudinales, transversales, torsionales).

Como el hormigón se degrada, al sufrir los sucesivos ciclos de hielo/deshielo, las frecuencias fundamentales se reducen, al mismo tiempo, y estas reducciones son las que se utilizan para cuantificar, de alguna forma, la durabilidad del hormigón. Al proceder de esta manera, se generan ruidos molestos a la par que pérdidas importantes de tiempo.
For many years it has been standard practice to determine the durability of concrete in the laboratory by measuring the changes in the fundamental resonance frequencies of concrete speciments after freeze-thaw cycling. The current standard test method has been unchanged for twenty-five years (ASTM C215-60).

In this test, concrete specimens are subjected to sound waves in the audible range and the resulting resonant vibrations are measured or compared in order to find the fundamental frequencies (transverse, longitudinal or torsional). As the concrete degrades from freeze-thaw cycling, the fundamental frequencies are reduced. These reductions are used to calculate a measure of the durability of the concrete. Finding these fundamental frequencies is time consuming and generates a great deal of unpleasant noise. 
Recientemente hemos tenido ocasión de ensayar un gran número de probetas con poca mano de obra.

También sería deseable utilizar probetas más pequeñas que las habituales con vistas, tanto a la economía de materiales, como a la facilidad de preparación, ensayo y almacenamiento, de forma que pueda jugar con una mayor gama y combinaciones de variables de ensayo.

Estos problemas nos introdujeron a buscar otros métodos de ensayos que dieran lugar a las mismas medidas pero de mayor rapidez y con probetas más pequeñas.

En la norma ASTM C215-60, una viga de hormigón se apoyaba sobre sus puntos nodales de modo que pueda vibrar transversalmente sin ninguna restricción. Para ello se excita la probeta por el centro de una de sus caras verticales, mediante un dispositivo formado por un altavoz de audio al que se le ha incorporado una punta cónica de acero pegada al diagragma del altavoz. Las vibraciones de las probetas se recogen mediante una aguja fonocaptora (puede ser una cápsula de tocadiscos corriente) apoyada sobre la cara superior y cerca de uno de los extremos (ver fig. 1).

El dispositivo se excita, en la banda de 500 a $2.500 \mathrm{~Hz}$, mediante un oscilador y amplificador sintonizado a estas frecuencias. Las vibraciones alcanzan su máximo a la frecuencia de resonancia natural de la probeta.

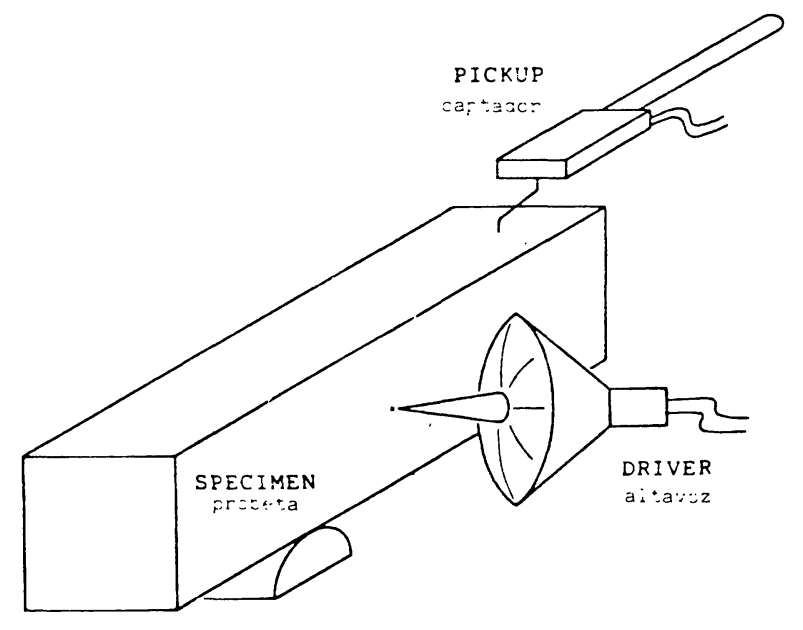

Fig. 1

Esquema del Módulo de Medición Acústica ASTM-215.

Schematic of ASTM-215 Sonic Modulus Measurement.
We have had occasion recently to test large numbers of specimens with limited manpower. We also desired to use smaller specimens than the usual size, partly in order to conserve materials and partly in order to be able to prepare, test and store specimens having more combinations of test variables. These problems forced us to look for an alternate test method that would produce the same measurements, only faster, on smaller samples.

In ASTM C215-60, a concrete beam is supported at nodal points so it may vibrate in the transverse mode without restriction. A driver, which is usually an audio loudspeaker modified with a steel-tipped cone fastened to the paper diaphragm, is positioned in the middle of one of the vertical sides of the specimen. A pickup, usually a phonograph cartridge, is placed onto one end of the top surface of the specimen (see Figure 1). The driver is forced by an oscillator and amplifier through the audio frequency range of about 500 to 2500 Hertz and causes the specimen to vibrate; the vibrations are largest at the natural resonant frequency of the specimen. In the most usual method of detection, the voltage applied to the driver and the output of the pickup are plugged into the horizontal and vertical inputs of an oscilloscope. The fundamental frequencies are found when amplitude from the pickup is largest. The transverse, longitudinal and torsional frequencies are determined by proper positioning of the driver and pickup. After freezethaw cycling, the relative dynamic modulus of elasticity (designated P) can be calculated for a concrete beam (see Figure 2).

$$
P_{\mathrm{C}}=\frac{N_{\mathrm{C}}^{2}}{N_{\mathrm{i}}^{2}} \times 100
$$

siendo

were

$P_{\mathrm{C}}=$ Módulo de elasticidad dinámico relativo después de haber subrido $c$ ciclos de hielo/deshielo, en porcentaje.

relative dynamic modulus of elasticity after $c$ cycles of freezing and thawing, in per cent.

$N_{\mathrm{i}}=$ Frecuencia fundamental de resonancia transversal inicial.

initial fundamental transverse resonant frequency.

$\mathrm{N}_{\mathrm{c}}=$ Frecuencia fundamental de resonancia transversal después de haber sufrido $c$ ciclos de hielo/deshielo.

fundamental transverse resonant frequency after $c$ cycles of freezing and thawing.

Fig. 2

Cálculo del Módulo Dinámico Relativo.

Calculation of Relative Dynamic Modulus. 


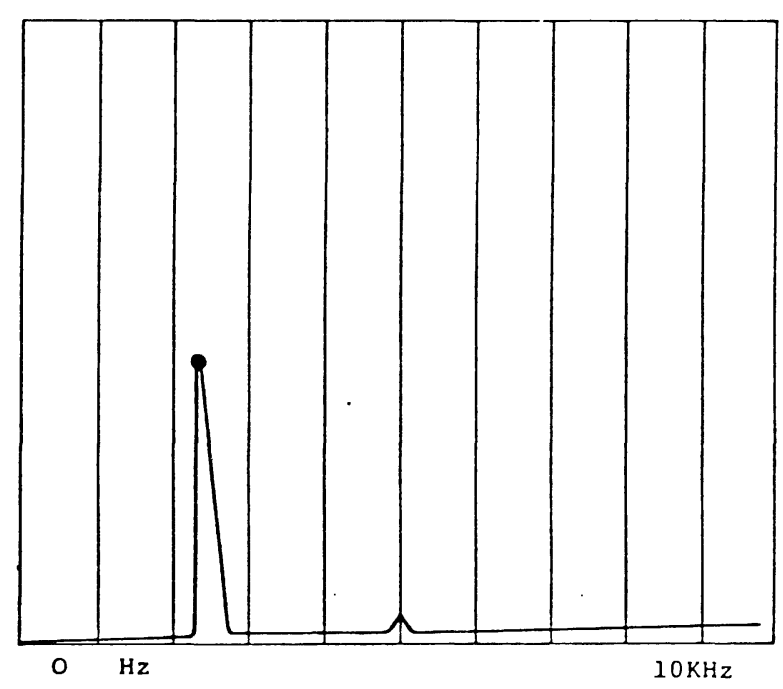

MKR: $2200 \mathrm{~Hz}$
Fig. 3.

Representación en pantalla de Tubo de Rayos Catódicos.

Screen Display from Cathode Ray Tube (CRT).

\section{VIBRATIONAL MODE}

Modo de vibración
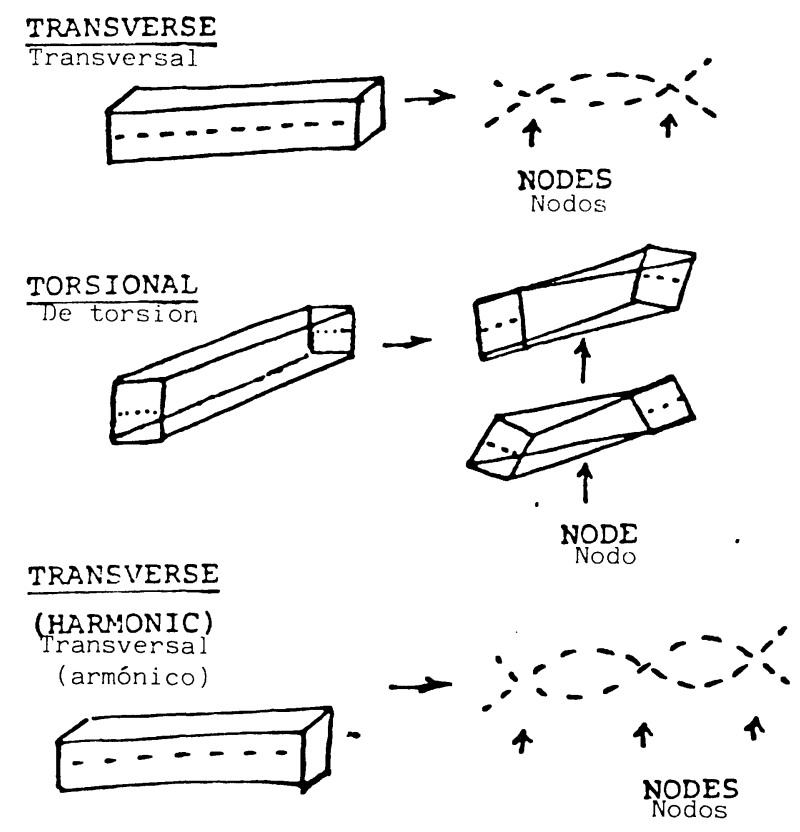

LONGI TUDINAL

Longitudinal

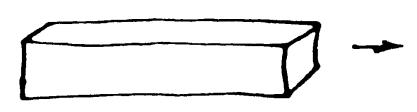

\section{Frecuencia}

\begin{tabular}{|c|c|c|}
\hline Espesor & No dañada & Dañada \\
\hline $3 "$ & 1760 & 960 \\
$4 "$ & 2180 & 1200 \\
$3 \times 4 "$ & 2960 & 1600 \\
3" & 4160 & 2360 \\
$4 "$ & 4920 & 2760 \\
$16 "$ & 5000 & 2840 \\
\hline
\end{tabular}

Frequency, $\mathrm{Hz}$

\begin{tabular}{|c|c|c|}
\hline Thickness & Undamaged & Damaged \\
\hline 3" & 1760 & 960 \\
$4 "$ & 2180 & 1200 \\
$3 \times 4 "$ & 2960 & 1600 \\
3" & 4160 & 2360 \\
$4 "$ & 4920 & 2760 \\
$16 "$ & 5000 & 2840 \\
\hline
\end{tabular}

Fig. 4

Típicas Resonancias de Vigas de Hormigón.

Resonances Typical of Concrete Beams. 
En la forma más habitual de detección, la tensión aplicada al excitador y la de salida del fonocaptor se aplican, después, a las placas horizontales y verticales respectivas de un osciloscopio. Cuando se alcanzan las frecuencias fundamentales la amplitud de la señal procedente del fonocaptor es máxima.

Las frecuencias, longitudinales, transversales y torsionales se obtienen situando en posiciones adecuadas el excitador y el captador.

Después de una sucesión de ciclos hielo/deshielo se puede calcular el módulo de elasticidad dinámico relativo (representado por $\mathrm{P})$ de una cierta viga de hormigón (ver fig. 2).

Hemos descubierto una técnica mucho más simple para determinar las frecuencias en una probeta de hormigón. Esencialmente consiste en golpear una probeta de hormigón y medir las frecuencias de vibración del mismo.

La amplitud y frecuencias de las vibraciones de resonancia se obtienen mediante un analizador de espectros "Hewlett-Packard" (mod. n. ${ }^{\circ} 3582 \mathrm{~A}$ ) que determina las frecuencias de la respuesta del hormigón a los golpes por medio de la transformada rápida de Fourier.

La amplitud de la respuesta en función de la frecuencia se puede poner de manifiesto en la pantalla de un TRC, donde los picos mayores pueden leerse directamente (fig. 3). Las distinciones entre frecuencias fundamentales y armónicas pueden hacerse, generalmente, comparando las alturas de los picos en los diversos modos de excitación. A igual que ocurre con el método de la ASTM G215-60, hay que usar la disposición de excitador y captador para distinguir entre frecuencias longitudinales, transversales y torsionales (ver fig. 4).

En la fig. 5 se presenta el equipo utilizado en la realidad. Un equipo similar se emplea en el osograma especial para determinar las vibraciones de resonancia en los módulos de alunizaje.

Nosotros hemos empleado un kit piezotrónico PCB N. K291B que está constituido por un acelerómetro que sustituye a la aguja fonocaptora, un martillo instrumentado que actúa como disparador para el comienzo de la adquisición de datos, y dos pequeños amplificadores.

Para su funcionamiento, el acelerómetrocaptador se fija a un extremo de la viga con un
We have found a much simpler technique to determine the fundamental frequencies of a concrete specimen. Essentially, the technique involves tapping a concrete sample and measuring the frequencies at which the concrete vibrates. The amplitude and irequency of the resonant vibration are obtained using a Hewlett-Packard Spectrum Analyzer (Model No. 3582A) that determines the frequencies of the concrete response to the tap via a Fast Fourier Transform. The amplitude of the concrete response versus frequency is displayed on a CRT and the major peaks can be read directly (see Figure 3). The distinction between the fundamental frequency and harmonics can generally be made by comparing peak heights in various excitation modes. As with ASTM C215-60, positioning must be used to distinguish transverse, longitudinal and torsional frequencies (see Figure 4). In Figure 5 the actual-set up that we used is shown. This type of equipment was used in the space program to determine resonant vibrations in the lunar landing modules.

We have used a PCB Piezotronics Kit No. K291B, which consists of an accelerometer (see Figure 6) (which corresponds to the phonograph pickup), an instrumented hammer (which acts like a trigger to start data acquisition) and two small amplifiers. In operation, the pickup accelerometer is fastened to the beam end with a bit of microcrystalline wax and the beam is struck lightly the hammer. Within a second, a curve of amplitude versus frequency is produced on the CRT. A dot marker may then be moved by a variable resistance control to coincide with the peak maximum, and its frequency value is diplayed. The whole process takes less than a minute per specimen, in contrast to the continuous driving method of the current ASTM C215-60, which often takes 10 minutes or so to scan the range and confirm it. Many times, we were unable with ASTM C215-60 to determine the fundamental frequency for specimens that were seriously deteriorated or undersized; this problem was never observed when we used the method we are proposing here. For the smaller test specimens no change in procedure was necessary.

The system may also be used without an instrumented hammer. If single-channel input is selected, the pickup accelerometer is adhered to the beam, the specimen is tapped, and the resulting frequency response is displayed on the screen.

You may be interested in some typical results comparing the two methods. Figure 7 shows the transverse fundamental frequencies of concrete beams after different periods of 
poco de cera microcristalina y se golpea suavemente al otro extremo con el martillo.

En el espacio de 1 seg. se genera una curva, en la pantalla de TRC, de amplitud en función de la frecuencia. Para hacer aparecer en pantalla el valor numérico de esta frecuencia hasta desplazar sobre la pantalla un cursor accionado por un potenciometro del aparato. Cuando se sitúa éste sobre un pico cualquiera, se puede leer su frecuencia en un ángulo de la pantalla. En la totalidad del proceso se emplea menos de $1 \mathrm{~min} . /$ probeta en oposición al método de excitación continua de la vigente Norma ASTM C215-60, que necesita alrededor de 10 min. para explorar toda la banda y confirmar las lecturas.

En muchas ocasiones no fuimos capaces de determinar con este procedimiento la frecuencia fundamental en probetas seriamente deterioradas o deformadas. Este problema nunca ha surgido usando el nuevo método que proponemos aquí.

Con las probetas de ensayo de menor tamaño no fue preciso introducir ninguna variación en el método, ya que éste permite, también, prescindir del martillo.

Para ello se utiliza una sola entrada del osciloscopio, por lo que se envía la señal inducida por el acelerómetro, cuando se golpea la probeta, la imagen de la señal, aparece entonces en pantalla.

Si se comparan algunos resultados típicos de ambos métodos, la fig. 7 muestra las frecuencias fundamentales transversales de vigas de hormigón después de haber sufrido algunos ciclos de hielo/deshielo.

En los valores en que se observan discordancias entre ambos son aquellos en que nuestro operador tuvo dificultades para fijar el valor por el método de la Norma ASTM C215-60.

Nos complacería proponer este método como alternativo al actualmente empleado. Somos conscientes de que tiene las ventajas de una mayor velocidad y una superior precisión, aunque también comprendemos que sería preciso ensayos más exhaustivos antes de su aceptación definitiva.

No obstante, este comité podría decidirse a obtener la necesaria información sobre el método para conseguir su aceptación en Norma. freeze-thaw cycling. Where the two methods disagree in values it was because our operator had difficulty determing the value by ASTM C215-60.

We would like to propose this method as an alternate to the method now used. We feel it has the advantages of greater speed and higher accuracy. We realize that more exhaustive testing of this method must be done before its acceptance. However, this committee could best decide how to obtain the necessary information on the method to obtain its approval as a standard.

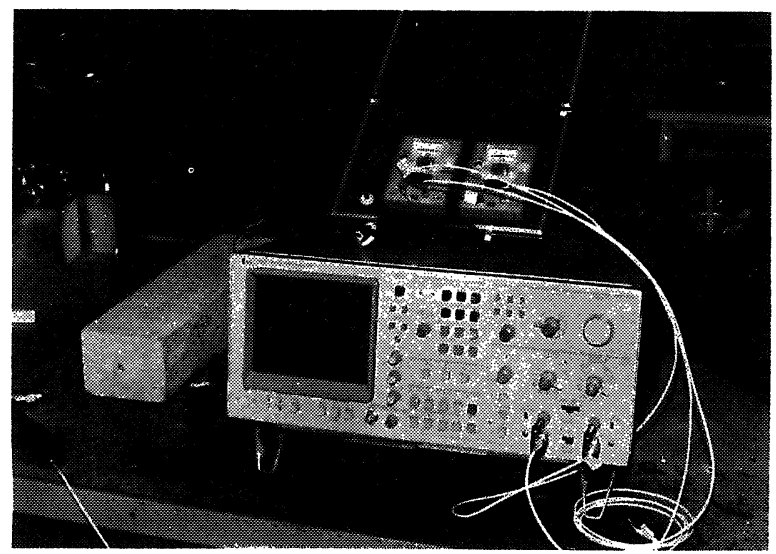

Fig. 5

Fotografía del Montaje del Equipo Completo. Photo of the Complete Equipment Set-Up.

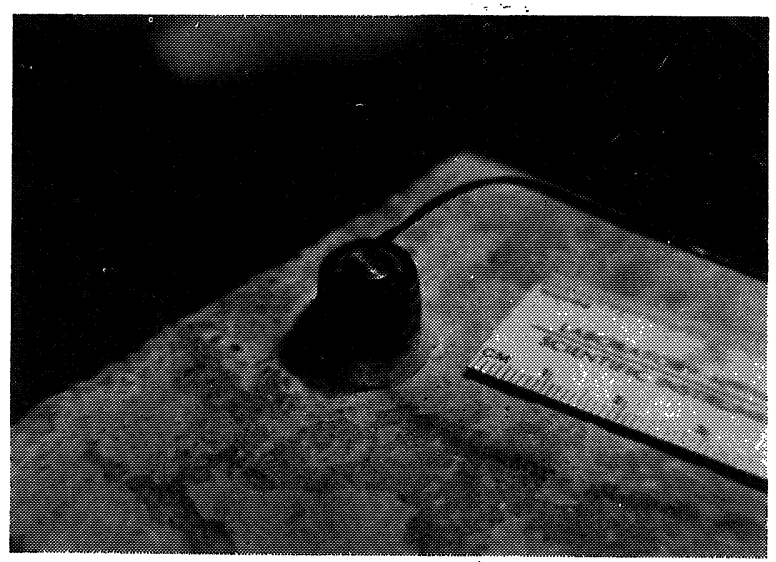

Fig. 6 Fotografía del Acelerómetro. Photo of the Accelerometer Pickup. 
Frecuencias Fundamentales Transversales

\begin{tabular}{|c|c|c|}
\hline $\begin{array}{c}\text { Tamaho de la } \\
\text { Probeta }\end{array}$ & Método C-215 & $\begin{array}{c}\text { Analizador } \\
\text { de Spectrum }\end{array}$ \\
\hline $3 \times 4 \times 16 "$ & $1762 \mathrm{~Hz}$ & $1760 \mathrm{~Hz}$ \\
$3 \times 4 \times 16 "$ & 1725 & 1720 \\
$3 \times 4 \times 16 " \star$ & 728 & 620 \\
\hline $3 \times 3 \times 14 "$ & 1936 & 1860 \\
$3 \times 3 \times 14 "$ & 1912 & 1920 \\
$3 \times 3 \times 14 " \star$ & 1243 & 980 \\
\hline $1 \times 1 \times 11^{\prime \prime}$ & 1148 & 1160 \\
$1 \times 1 \times 1{ }^{\prime \prime}$ & 1077 & 1060 \\
$1 \times 1 \times 11^{\prime \prime}$ & 977 & 980 \\
$1 \times 1 \times 11^{\prime \prime \star}$ & 501 & 400 \\
\hline
\end{tabular}

* Dañado por ciclos de hielo/deshielo.
Fundamental Transverse Frequencies

\begin{tabular}{|l|l|l|}
\hline Specimen Size & C-215 Method & $\begin{array}{c}\text { Spectrum } \\
\text { Analyzer }\end{array}$ \\
\hline $3 \times 4 \times 16 "$ & $1762 \mathrm{~Hz}$ & $1760 \mathrm{~Hz}$ \\
$3 \times 4 \times 16 "$ & 1725 & 1720 \\
$3 \times 4 \times 16 " *$ & 728 & 620 \\
\hline $3 \times 3 \times 14 "$ & 1936 & 1860 \\
$3 \times 3 \times 14 "$ & 1912 & 1920 \\
$3 \times 3 \times 14 " *$ & 1243 & 980 \\
\hline $1 \times 1 \times 11 "$ & 1148 & 1160 \\
$1 \times 1 \times 11 "$ & 1077 & 1060 \\
$1 \times 1 \times 11 "$ & 977 & 980 \\
$1 \times 1 \times 11 " *$ & 501 & 400 \\
\hline
\end{tabular}

* Damaged by freeze-thaw cycling.

Fig. 7

Banda de resultados - Viejos Métodos contrafrente

Nuevos Métodos

Crossover Results - Old Method vs. New Metod.

\section{publicaciones del i.e.t.c.c.}

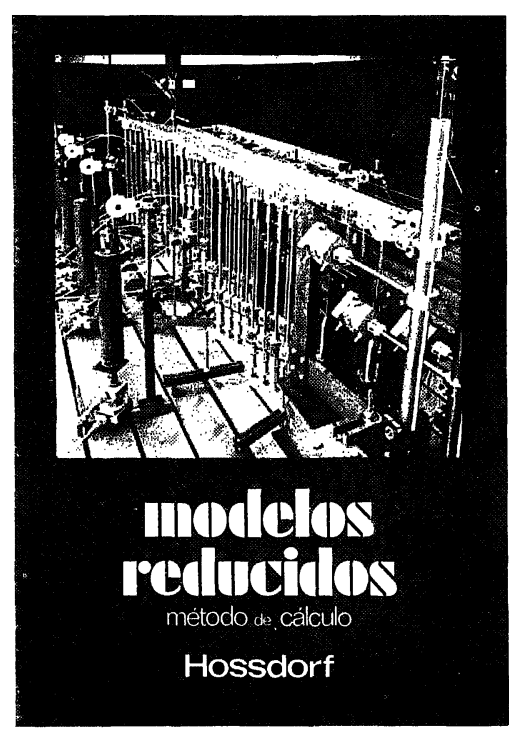

Modelos reducidos. Método de cálculo

H. Hossdorf, Ingeniero Civil

La técnica de los ensayos en modelos reducidos de estructuras sufre hoy dia una decisiva metamorfosis. Hasta hace poco era un medio más bien de artesania, que no siempre era tomado en serio por los académicos teorizantes para comprender el comportamiento resistente de las estructuras complejas $y$ al que se acudió las más de las veces, como a un último remedio debido a sus indiscutibles insuficien cias. Sin embargo, en poco tiempo y gracias a su conexión con los ordenadores digitales, se ha transformado en un instrumento cientificamente valioso, que no puede quedar a un lado en la practica diaria del Ingeniero Proyectista.

Un volumen encuadernado en cartoné plastificado con lomo de tela de $17 \times 24 \mathrm{~cm}$ compuesto do 250 páginas, 158 figuras $y$ fotografias.

Precios: 1.800 ptas.; \$ USA 26.00

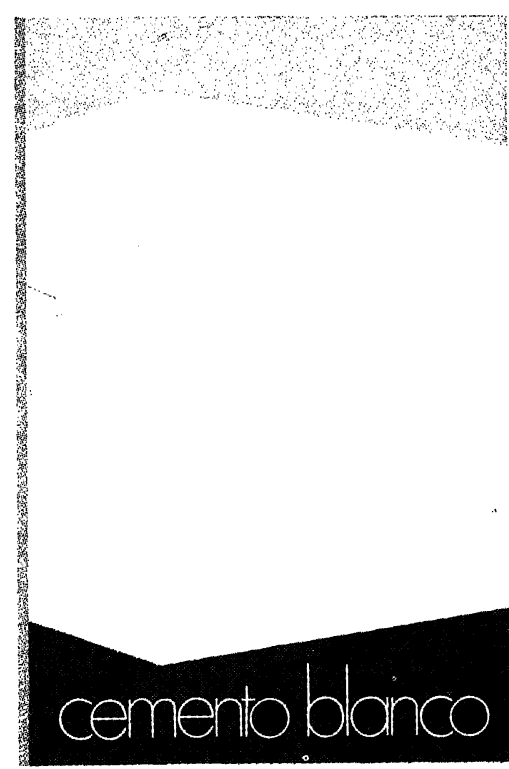

Cemento blanco

Juliàn Rezola

Ingeniero Quimico Dipl. I. O. S.

Sabido es que existe una extensa y documentada bibliografia sobre el cemento gris: en cambio, no puede decirse lo mismo acerca del cemento portland blanco, ya que los escritos existentes se refieren tan sólo a algunas peculiaridades que le distinguen de aquèl.

El autor nos ofrece sus profundos conocimientos y su larga experiencia tanto en laboratorio como en fabricación.

La parte descriptiva del libro se complementa con gráficos, diagramas y fotogyrafias de gran utilidad destinados a consegurir la aplicación apropiada de este aglomerante.

Un volumen encuadernado en cartoné policerado, de $174: 243 \mathrm{~cm}$ compunsto de 395 pacinas.

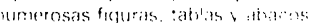

Precios: España 1.700 ptas.: extranjero. \$24.00.

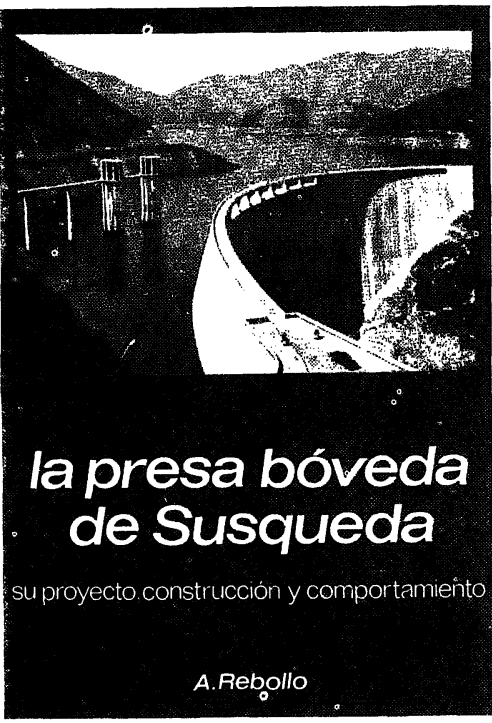

La presa bóveda de Susqueda

A. Rebollo,

Dr. Ingeniero de Caminos

El esfuerzo del constructor de presas se sitúa por su pretensión de perennidad, a contracorriente de las tendencias de la civilizacion actual, caracterizada por lo fungible. Pueden evocarse las 10.000 grandes. presas en funcionamiento o en construcción que estan envejeciendo y reclaman los cuidados gerontológicos para mantener y perfeccionar su servicio y garantizar su inalienable pretension de perennidad. En la medida en que todas nuevas obras, grandes o pequeñas, son portadoras de riesgos ecologicos $y$, a veces, catastroficos, que aumentan con el envejeciniento, la gerontologia de las presas es todo un emplazo. La accion adelantada de Anturo Rebollo un emplazo. La acción ade ture camino a seguir para todos los que aren su propia obra con

Un volumen encuadernado en cartone plastificado Un volumen encuadernado en cartone plastificado 408 páginas, 330 figuras y fotografias y 39 tablas. Precios: 1.700 ptas.; extranjero, \$ USA 24.00. 